\title{
Modelling the seasonality of subsurface light and primary production in the Arabian Sea
}

\author{
John Brock ${ }^{1}$, Shubha Sathyendranath ${ }^{2}$, Trevor Platt ${ }^{1}$ \\ ${ }^{1}$ Biological Oceanography Division, Bedford Institute of Oceanography, PO Box 1006, Dartmouth, Nova Scotia, Canada B2Y 4A2 \\ ${ }^{2}$ Department of Oceanography, Dalhousie University, Halifax, Nova Scotia, Canada B3H 4 J1
}

\begin{abstract}
Seasonal changes in mixed-layer depth and phytoplankton biomass in the Arabian Sea are assessed with climatologies of ship-based hydrographic measurements and ocean-color observations from satellite. At the close of the intermonsoons in November and especially May, the open Arabian Sea resembles the stereotypic, unperturbed tropical ocean, with a thin oligotrophic mixed layer and a pronounced subsurface chlorophyll maximum. Both the northeast and southwest monsoons disrupt this typical tropical hydrography through mixed-layer deepening and eutrophication in the central and northern Arabian Sea. Computations using a spectral model of light penetration suggest that seasonal changes in mixed-layer thickness and phytoplankton concentration result in pronounced fluctuations through the annual cycle in the radiant flux reaching the base of the mixed layer. At the close of the fall and spring intermonsoons the base of the model euphotic zone is in the thermocline across all of the open Arabian Sea. The euphotic zone appears to rise into the mixed layer of the northern Arabian Sea during both the winter and summer monsoons. Strong seasonality in total primary production and its partitioning between the mixed layer and thermocline is predicted by a photosynthesis-irradiance model for a site in the western Arabian Sea (14.36 $\left.\mathrm{N}, 57.38^{\circ} \mathrm{E}\right)$. Modeled mixedlayer primary production depicts an intense peak for the southwest monsoon and a secondary northeast monsoon peak separated by intermonsoon periods of low production. During the fall and spring intermonsoons, in the presence of a subsurface chlorophyll maximum, the model estimate of primary production in the thermocline exceeds that in the mixed layer. Our model calculations suggest that the subsurface chlorophyll maximum present in the Arabian Sea during the spring intermonsoon is a precursor of the regional, summer, phytoplankton bloom.
\end{abstract}

\section{INTRODUCTION}

Light propagating in Case 1 ocean waters (Morel \& Prieur 1977, Gordon \& Morel 1983) is attenuated mostly through absorption by phytoplankton and by pure seawater. The Arabian Sea exhibits extreme, and coupled, seasonal and geographic variability in shortwave radiation (Hastenrath \& Lamb 1979b), phytoplankton biomass (Currie et al. 1973, Krey \& Babenerd 1976, Banse \& McClain 1986, Banse 1987b, Bauer et al. 1991, Brock et al. 1991, Brock \& McClain 1992) and mixed-layer depth (Colburn 1975, Molinari et al. 1986. Hastenrath \& Greischar 1989, Rao et al. 1989) because of forcing by the monsoons. Given the dependence of photosynthesis on light and autotrophic biomass, these biological and hydrographic changes imply strong spatial and temporal gradients in primary production (Kabanova 1968, Babenerd \& Krey 1974, Qasim 1982), and high variability in the relative importance of production in the mixed layer and in the thermocline.

The goal of this paper is to assess seasonal changes in submarine irradiance and the vertical partitioning of photosynthesis in the Arabian Sea. The objectives are to: (1) summarize the variation in mixed-layer depth and phytoplankton biomass through the annual cycle; (2) estimate by season the irradiance reaching the thermocline; and (3) evaluate the contribution from, and the importance of, production below the mixed layer in the western Arabian Sea.

Submarine light is of particular relevance to the occurrence of a subsurface chlorophyll maximum (SCM) within the Arabian Sea, in the upper thermocline, at sites with an oligotrophic mixed layer (Yentsch 1965, Saijo 1973, Krey \& Babenerd 1976, Bauer et al. 1991, Mantoura 1991, Hay et al. 1992). These submerged phytoplankton blooms are seasonally and geo- 
Fall Intermonsoon (November)

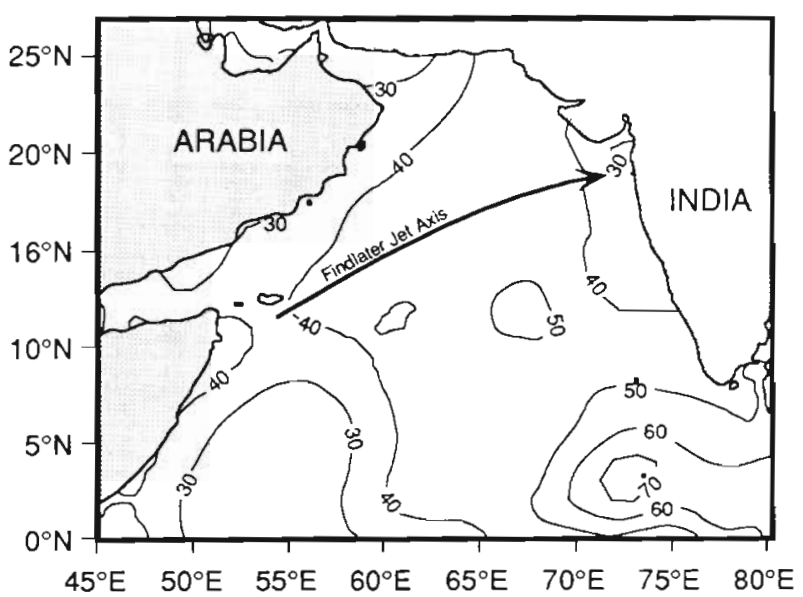

Spring Intermonsoon (May)

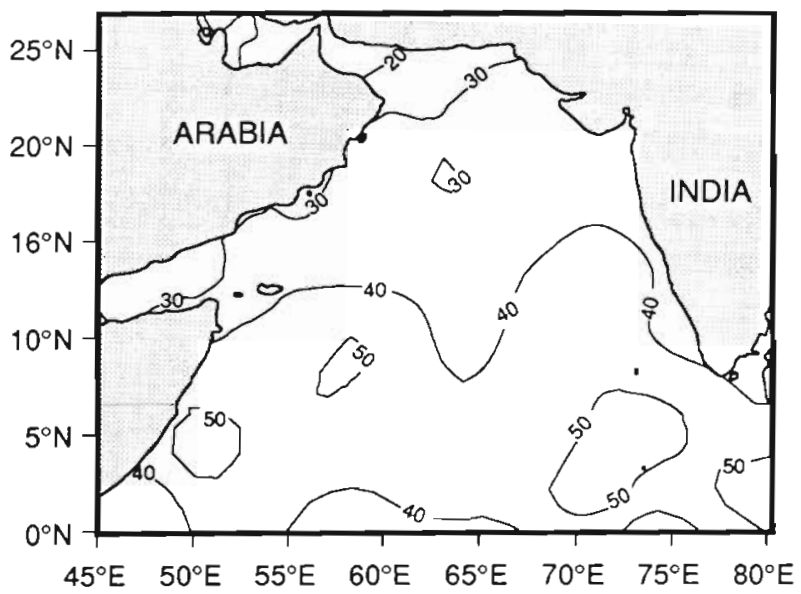

Northeast Monsoon (February)

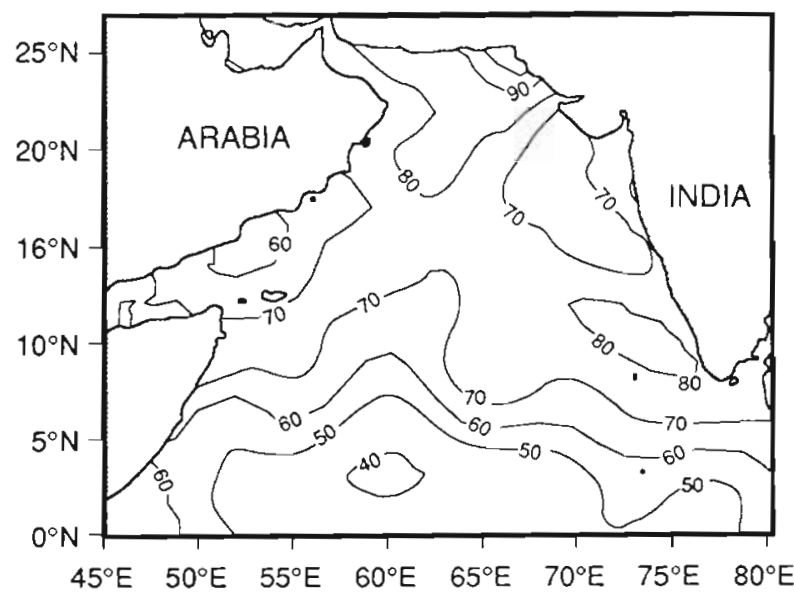

Southwest Monsoon (August)

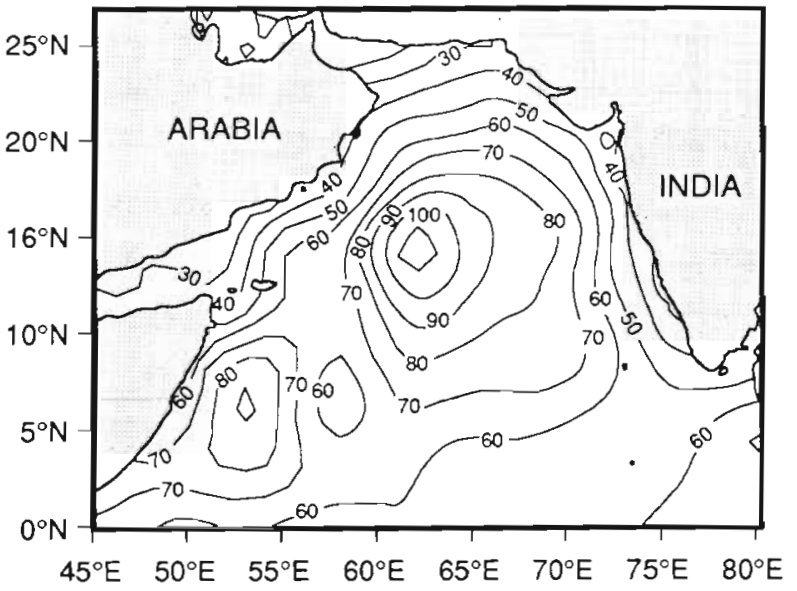

Fig. 1. Monthly mixed-layer depth fields (m) (Hastenrath \& Greischar 1989) used in light modeling and representing the 4 seasons of the annual monsoon cycle. Mean position of the Findlater Jet in July is shown by the arrow on the map of mixed-layer depth in November

graphically distinct from surface-layer blooms driven by the monsoon winds (Banse \& McClain 1986, Banse 1987b, Bauer et al, 1991, Brock et al. 1991, Brock \& McClain 1992). Blooms in the upper thermocline should differ fundamentally from those in the mixed layer, because they usually occur within or directly adjacent to a sharp nitricline and near the vertical turbulence minimum (Ryther \& Menzel 1965, Ryther et al. 1966, Mann \& Lazier 1991).

Ocean-color sensors are incapable of observing SCM layers, because about $90 \%$ of the ocean-color signal derives from the first attenuation depth (Gordon \& McCluney 1975), usually shallower than the upper thermocline, the typical site of the SCM in well stratified, tropical waters (Yentsch 1965, Venrick et al. 1973, Gieskes et al. 1978, Hayward et al. 1983). However, cli- matological mixed-layer fields can be used to constrain the vertical chlorophyll profiles in the Arabian Sea. Inclusion of this ancillary hydrographic information allows the implementation of a submarine light model to estimate the light at the base of the mixed layer, which is assumed to have vertically uniform phytoplankton biomass.

\section{APPROACH}

The monthly mixed-layer depth fields (Hastenrath \& Greischar 1989) (Fig. 1) and cloudiness fields from the Max Planck Institute, Hamburg, Germany (Wright 1988) were both interpolated to $1^{\circ}$ from an original resolution of $2^{\circ}$. A monthly climatology of phytoplankton biomass (Fig. 2) for the Arabian Sea was generated by 

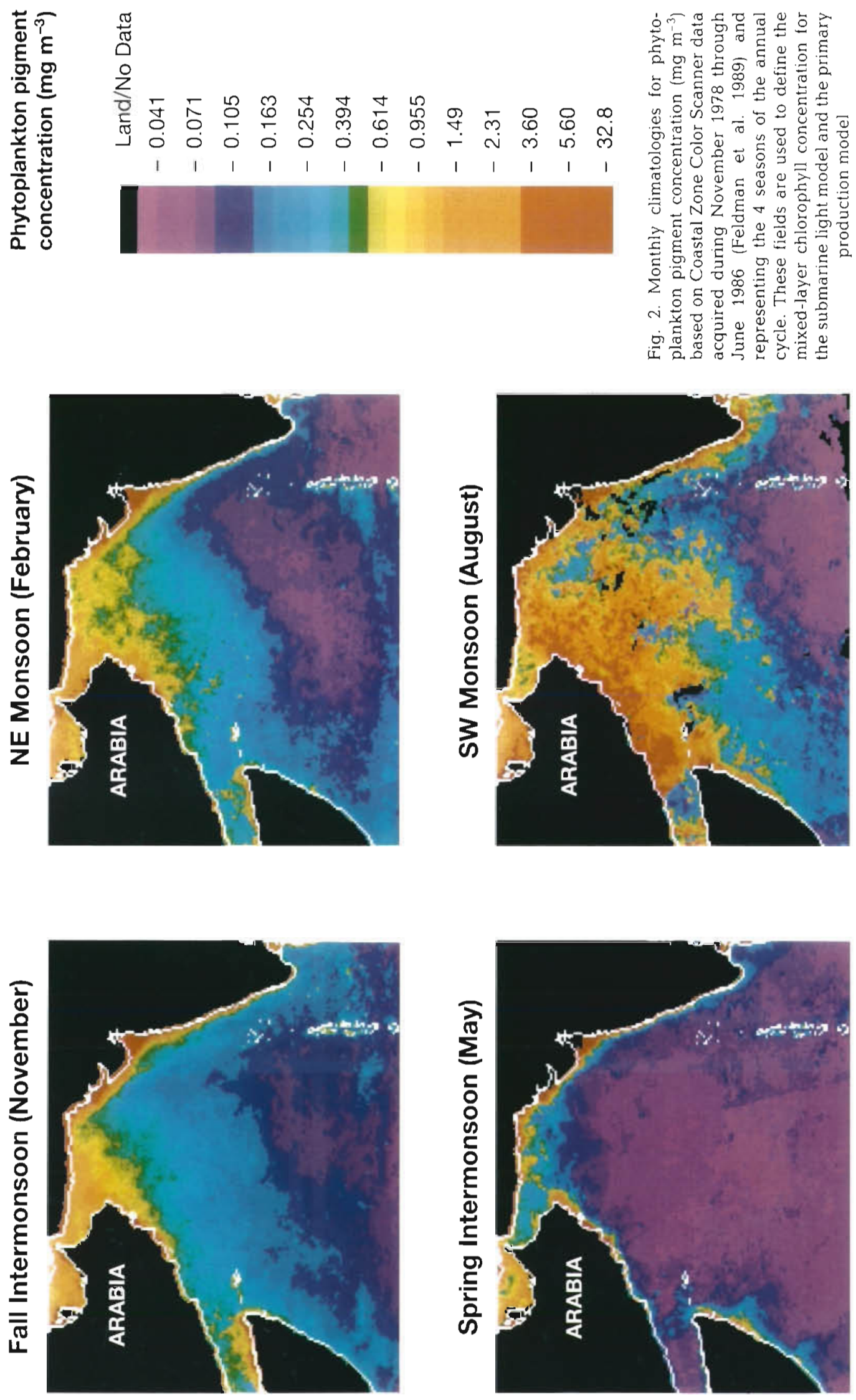
Table 1. Data sets used in this study

\begin{tabular}{|lll|}
\hline $\begin{array}{l}\text { Variable } \\
\text { Mixed-layer phytoplankton }\end{array}$ & Observational basis & Comment \\
$\begin{array}{l}\text { Vertical phytoplankton } \\
\text { biomass distribution }\end{array}$ & $\begin{array}{l}\text { High performance liquid chromatography } \\
\text { analysis of water samples }\end{array}$ & $\begin{array}{l}\text { Based on monthly average } \\
\text { fields from NASA/GSFC }\end{array}$ \\
$\begin{array}{ll}\text { Mixed-layer depth } \\
\text { during Cruise SO-42 of the West } \\
\text { German RV 'Sonne' (May 24, 1986) }\end{array}$ \\
$\begin{array}{l}\text { Subsurface temperature and salinity } \\
\text { soundings }\end{array}$ & $\begin{array}{l}\text { Based on the Master Oceanographic } \\
\text { Observation Data Set compiled by the } \\
\text { Fleet Numerical Oceanography Center, }\end{array}$ \\
& $\begin{array}{l}\text { Monterey, California, USA } \\
\text { Climatology based on the COADS } \\
\text { data set }\end{array}$ & $\begin{array}{l}\text { Provided by the Max Plank Institut für } \\
\text { Meteorologie, Hamburg, Germany }\end{array}$ \\
\hline
\end{tabular}

Fall intermonsoon (November)

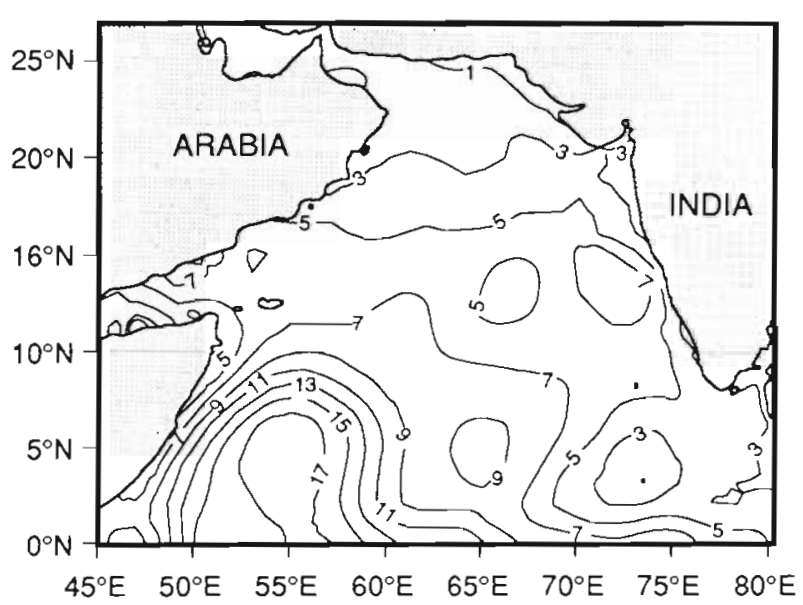

Spring Intermonsoon (May)

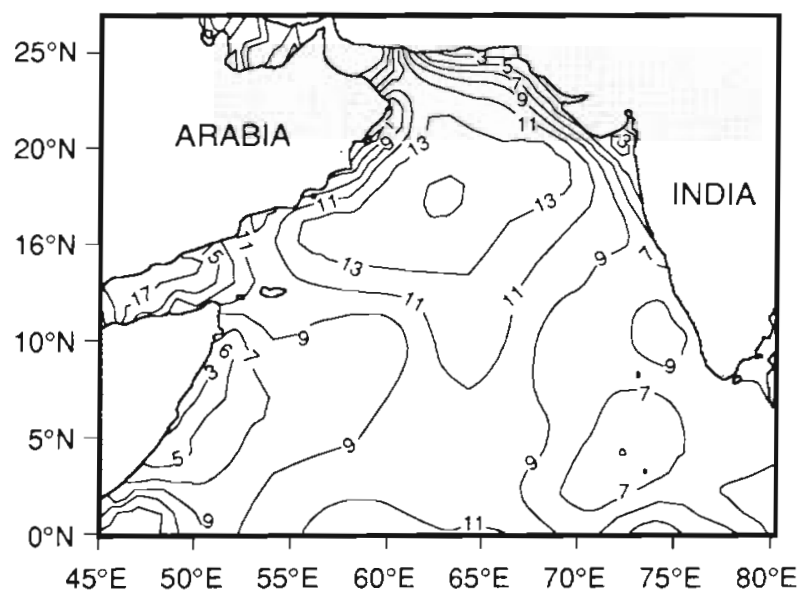

Northeast Monsoon (February)

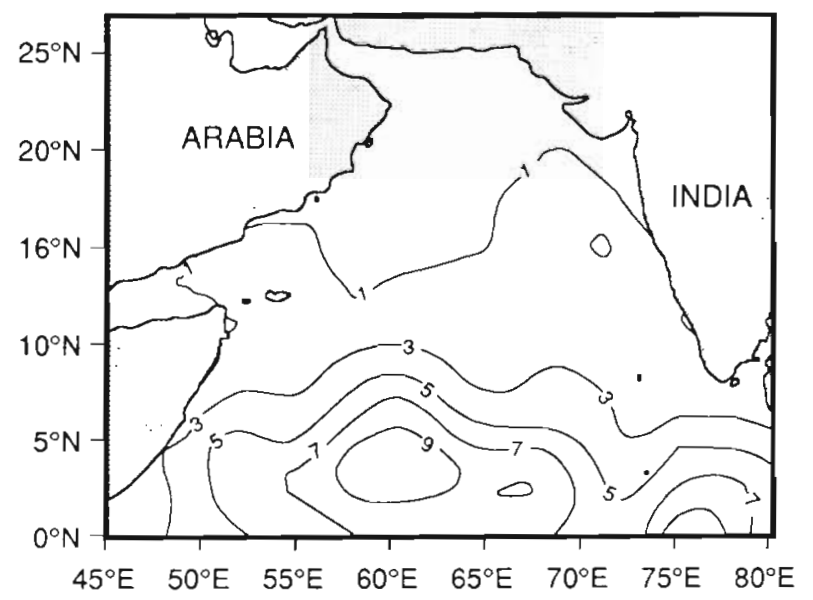

Southwest Monsoon (August)

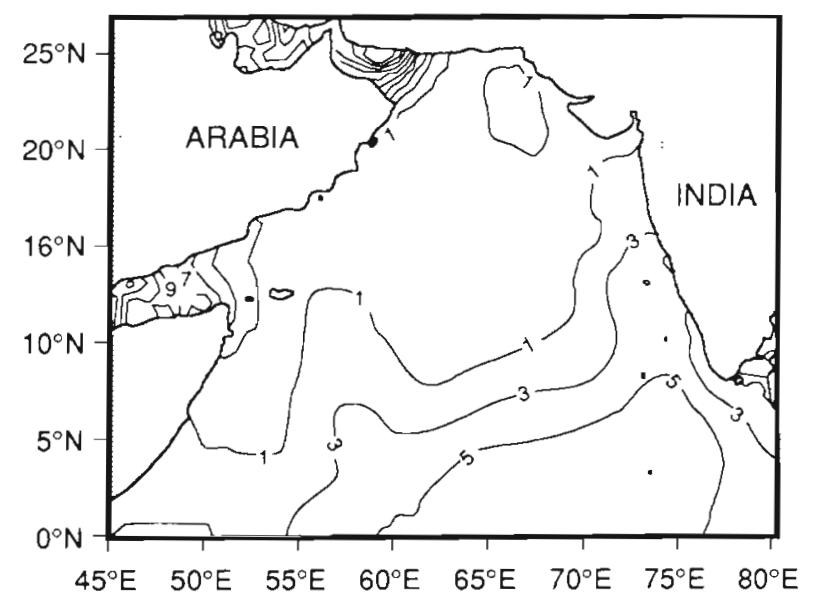

Fig. 3. Maps depicting model predictions of the mean daily percent of surface shortwave radiation at the mixed-layer depth for Day 15 of 4 different months representing the close of each of the 4 annual seasons of the Arabian Sea 
averaging on a $1^{\circ} \times 1^{\circ}$ grid the monthly Level 3 phytoplankton pigment concentration composites for the overall life of the Coastal Zone Color Scanner (CZCS), November 1978 through June 1986 (Feldman et al. 1989). The data sets used in this study are the MONTHLYPST CZCS data product from the Nimbus Project Office at NASA Goddard Space Flight Center (Feldman et al. 1989), monthly mixed-layer depth (Hastenrath \& Greischar 1989) and cloud-cover (Wright 1988) climatologies, and water-column measurements of phytoplankton pigment concentration (Hay et al. 1992). Table 1 summarizes the characteristics of these data sets.

Incident irradiance and submarine light were modeled at $1^{\circ}$ spatial resolution over the entire Arabian Sea ( 0 to $28^{\circ} \mathrm{N}, 45$ to $80^{\circ} \mathrm{E}$ ) for months considered to best represent the hydrographic conditions that pertain at the end of each season. These 4 annual seasons are the fall intermonsoon (September-November), the northeast monsoon (December-February), the spring intermonsoon (March-May), and the southwest monsoon (June-August). Unlike some other definitions of the seasons of the Arabian Sea (Webster 1987, Schott et al. 1990), these designations are based on the mean oceanographic, not atmospheric, conditions.

Light modeling. The direct and diffuse components of spectral surface irradiance for cloud-free skies were estimated for Day 15 of each month using the model of Bird (1984) as implemented in Sathyendranath \& Platt (1988). Cloud-cover correction was adapted from the model of Paltridge \& Platt (1976) as in Platt et al. (1991) using the monthly cloud climatology of the Max Planck Institute (Wright 1988). The spectral model of Sathyendranath \& Platt $(1988,1989)$ was used to compute the penetration of direct and diffuse components of the submarine light field through a mixed layer whose monthly mean depth and phytoplankton biomass were described by the climatologies of Hastenrath \& Greishar (1989) and the CZCS, respectively. In this implementation, the satellite-observed phytoplankton biomass is assumed to represent vertically-uniform, mixed-layer biomass.

The spectral irradiances at the sea surface and at the base of the mixed layer were integrated over the wavelength range of interest in photosynthesis (400 to $700 \mathrm{~nm}$ ) to evaluate the percentage of light transmitted through the mixed layer. The calculations were repeated for every position on a $1^{\circ} \times 1^{\circ}$ grid for the 4 months under consideration to produce the maps in Fig. 3.

Modeling of primary production. We computed primary production through the annual cycle at the site $\left(14.36^{\circ} \mathrm{N}, 57.38^{\circ} \mathrm{E}\right)$ where a vertical chlorophyll profile was measured by the RV 'Sonne' on May 24, 1986 (Fig. 4 a). We chose this location because this recent profile

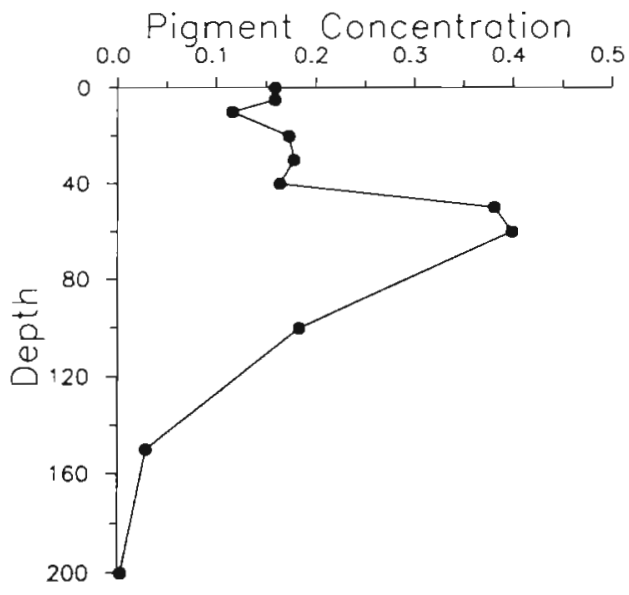

a

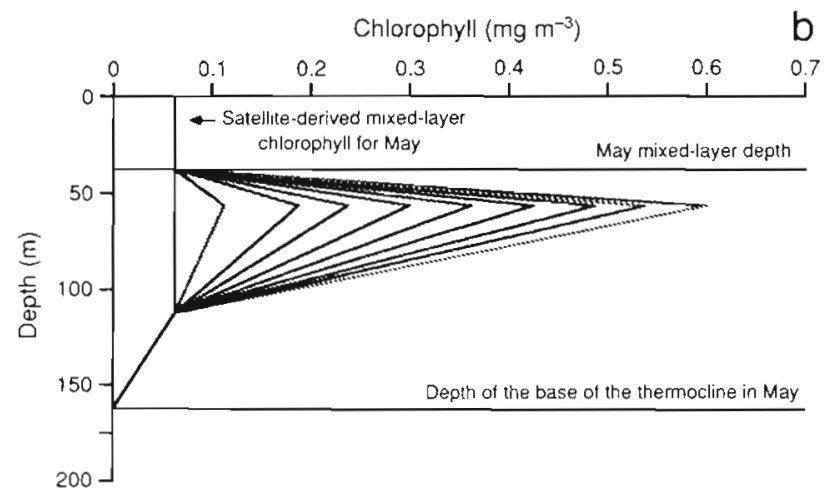

Fig. 4. (a) Vertical chlorophyll ( $\mathrm{mg} \mathrm{m}^{-3}$ ) profile observed by the RV 'Sonne' in the western Arabian Sea at $14.36^{\circ} \mathrm{N}$, $57.38^{\circ} \mathrm{E}$ on May 24, 1986. (b) Representation of vertical chlorophyll ( $\mathrm{mg} \mathrm{m}^{-3}$ ) profile used in the submarine light and primary production models

represents the hydrographic state in late May at the very end of the spring intermonsoon, and it is situated in the northwestern Arabian Sea in the region known to undergo monsoonal upwelling in summer (Smith \& Bottero 1977, Swallow 1984, Bauer et al. 1991, Brock et al. 1991. Hay et al. 1993).

The photosynthesis-irradiance model used was that of Platt \& Sathyendranath (1988). This is a non-linear, spectrally sensitive photosynthesis-light model which is applicable to the case of a non-uniform vertical biomass profile. Assuming no photoinhibition, 2 parameters describe the photosynthesis-light curve, the initial slope $\alpha^{B}\left[\mathrm{mg} \mathrm{C}(\mathrm{mg} \mathrm{chl} \mathrm{a})^{-1} \mathrm{~h}^{-1}\left(\mathrm{~W} \mathrm{~m}^{-2}\right)^{-1}\right]$ and the assimilation number $P_{\mathrm{m}}{ }^{B}\left[\mathrm{mg} \mathrm{C}(\mathrm{mg} \mathrm{chl} \mathrm{a})^{-1} \mathrm{~h}^{-1}\right]$, both normalized to chlorophyll concentration $B$. To optimize our production estimates for nutrient-rich conditions, we analyzed profiles of light and in situ primary production observed during the International Indian Ocean Expedition (Babenerd \& Krey 1974) during winter and summer periods of eutrophication to obtain $\alpha^{B}$ 

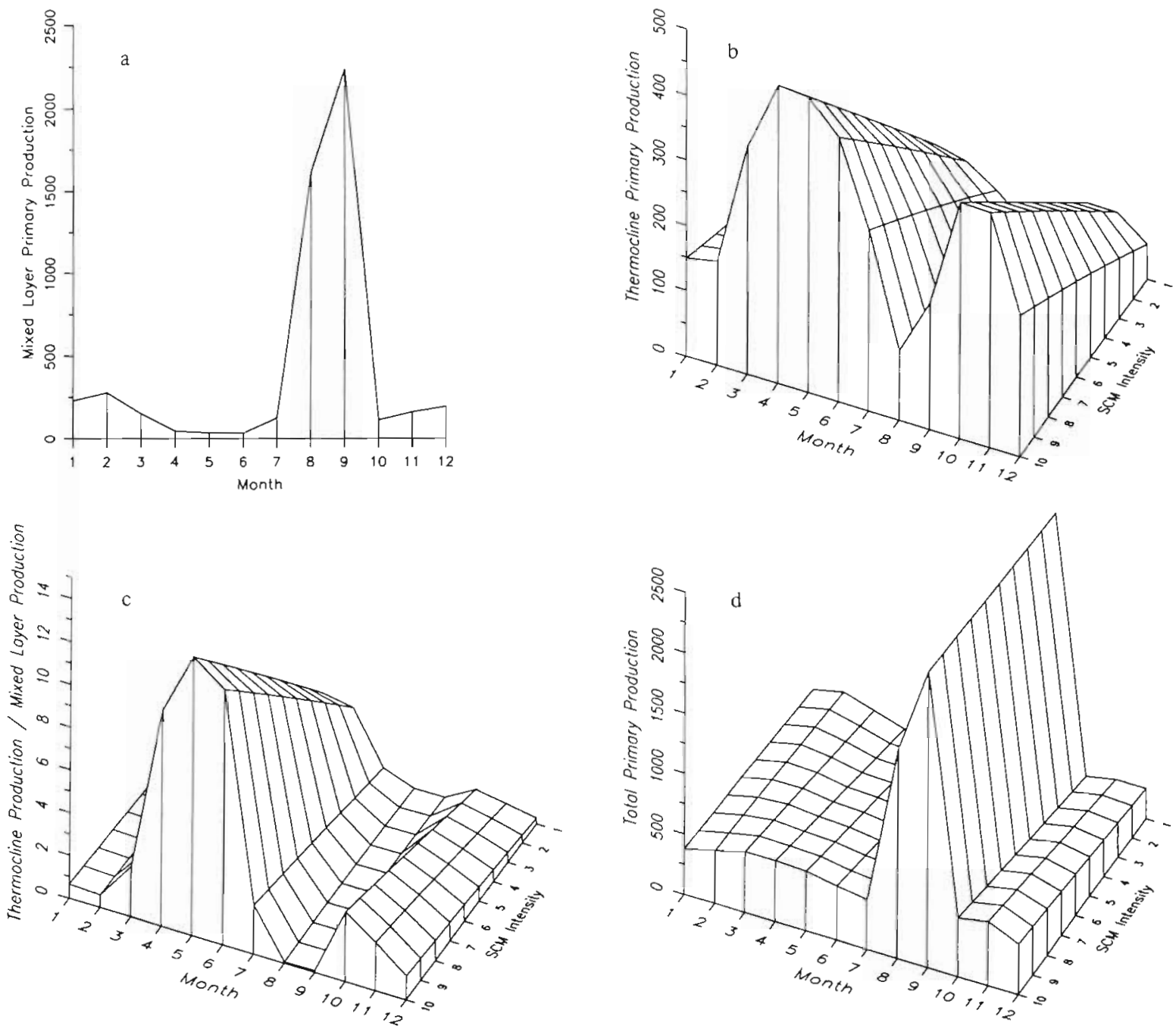

Fig. 5. Model estimate of primary production $\left(\mathrm{mg} \mathrm{C} \mathrm{m}^{-2} \mathrm{~d}^{-1}\right)$ for Day 15 of each month at site of the RV 'Sonne' station in the western Arabian Sea. The $z$-axis depicts the intensity of the subsurface chlorophyll maximum (SCM), varied for each month from nonexistent [a vertically uniform and oligotrophic $\left(0.06 \mathrm{mg} \mathrm{m}^{-3}\right)$ upper thermoclinel to an SCM with a chlorophyll concentration 10 times the oligotrophic baseline value. (a) Annual cycle of mixed-layer primary production. (b) Annual cycle of thermocline primary production. (c) Ratio of thermocline productivity to mixed-layer productivity through the year. (d) Annual cycle of total water-column primary production

and $P_{m}{ }^{B}$. Based on this study of the available profiles, we set $\alpha^{B}$ to $0.1 \mathrm{mg} \mathrm{C}(\mathrm{mg} \mathrm{chl} a)^{-1} \mathrm{~h}^{-1}\left(\mathrm{~W} \mathrm{~m}^{-2}\right)^{-1}$ and $P_{\mathrm{m}}{ }^{B}$ to $3.0 \mathrm{mg} \mathrm{C}(\mathrm{mg} \mathrm{chl} \mathrm{a})^{-1} \mathrm{~h}^{-1}$. The dependence of photosynthesis on available light in an oligotrophic mixed layer is likely to differ from that for regions of high nutrient fluxes or within the nutricline (Platt et al 1992), but due to lack of sufficient data from the Arabian Sea, we have not made allowances for such changes

The starting point is the equation of Smith (1936) for estimation of primary production, $P\left(\mathrm{mg} \mathrm{C} \mathrm{m}^{-3} \mathrm{~h}^{-1}\right)$ at any depth $z(m)$ :

$$
P(z)=\frac{B(z) \alpha^{B} I(z)}{\left\{1+\left[\alpha^{B} I(z) / P_{m}^{B}\right]^{2}\right\}^{1 / 2}}
$$

where $B(z)$ is the photosynthetically active biomass $\left(\mathrm{mg} \mathrm{m}^{-3}\right)$ and $I(z)$ is the photosynthetically active irradiance $\left(\mathrm{W} \mathrm{m}^{-2}\right)$ at depth $z$. Platt \& Sathyendranath (1988) and Sathyendranath \& Platt (1989) have revised this algorithm to include the dependence of primary production on the spectral and angular structure of the light field:

$$
P(z)=\frac{B(z) \Pi(z)}{\left\{1+\left[\Pi(z) / P_{m}^{B}\right]^{2}\right\}^{1 / 2}}
$$

where

$\Pi(z)=\sec \theta \int \alpha^{B}(z, \lambda) I_{d}(z, \lambda, \theta) \mathrm{d} \lambda+1.2 \int \alpha^{B}(z, \lambda) I_{s}(z, \lambda) \mathrm{d} \lambda$ 
In Eq. (3), $\lambda=$ wavelength; $\theta=$ the sun's zenith angle in water; subscript $s$ refers to the diffuse (sky) component of sunlight; subscript $d$ refers to the direct component.

Following Sathyendranath \& Platt (1989), the shape of the action spectrum is held constant, and its magnitude scaled such that its spectral average equals the value of $\alpha^{B}$ in the equation of Smith (1936).

The vertical profile of pigment biomass required by the primary production model was synthesized for each month at the site of the May 24, 1986, RV 'Sonne' station in the western Arabian Sea (Fig. 4b). The mixed-layer depth and thermocline thickness, and its vertically uniform phytoplankton biomass, were provided by the Hastenrath \& Greischar (1989) and CZCS-based climatologies. A gradually intensifying subsurface chlorophyll maximum was imposed upon an oligotrophic baseline pigment biomass of $0.06 \mathrm{mg}$ $\mathrm{m}^{-3}$ in the upper half of the thermocline. The baseline pigment biomass assigned to the upper thermocline is that observed by the CZCS for the mixed layer in May, and is in general agreement with historical chlorophyll profiles. It was assumed to decrease linearly to zero through the lower half of the thermocline, an approximation of the vertical profile observed by the RV 'Sonne'.

The monthly average daily rate of primary production was estimated separately for the mixed layer and thermocline (Fig. 5). Production from the thermocline was estimated for varying vertical biomass profiles ranging from no SCM to an intense deep chlorophyll peak 10 times the baseline value and at a depth $1 / 8$ of the thermocline thickness below the base of the mixed layer. The geometric form for the model SCM is a generalization of the distinct deep maximum observed in the upper thermocline by the RV 'Sonne' in late May of 1986.

\section{RESULTS AND DISCUSSION}

\section{Mixed-layer depth and phytoplankton biomass}

Although most previous work has focussed on either the northeast monsoon (Banse \& McClain 1986, Bauer et al. 1991) or the southwest monsoon (Smith \& Bottero 1977. Smith \& Codispoti 1980, Smith 1984, Swallow 1984, Naidu \& Rao 1990, Bauer et al. 1991, Brock et al. 1991, Brock \& McClain 1992) the transitional periods, or intermonsoons, are also very distinct seasons (Colburn 1975, Hastenrath \& Lamb 1979a, b). During both the fall intermonsoon and the spring intermonsoon, winds are weak (Hastenrath \& Lamb 1979a), cloudiness is diminished, and net heating results in a thin, oligotrophic mixed layer (Figs. 1 \& 2) (Colburn 1975, Molinari et al. 1986, Banse 1987b, Rao et al. 1989,
Naidu \& Rao 1990). The spring intermonsoon is the season of greatest heating (Hastenrath \& Lamb 1979b), and in May the mixed layer in the open Arabian Sea is mostly shallower than $50 \mathrm{~m}$ (Hastenrath \& Greischar 1989) (Fig. 1), and the climatological pigment concentrations observed by the CZCS are generally less than $0.1 \mathrm{mg} \mathrm{m}^{-3}$ (Fig. 2). Net oceanic heating during the fall intermonsoon, though not as extreme as during the spring intermonsoon, is also positive. In contrast, both the winter and summer monsoons result in regions of heat loss across much of the Arabian Sea (Hastenrath \& Lamb 1979b). We believe that the intermonsoon seasons ought to be recognized as periods of strong physical forcing that greatly impacts shallow hydrography and trophic state, and should not be viewed simply as quiescent intervals.

Historical vertical profiles of temperature and phytoplankton pigments (Yentsch 1965, Saijo 1973, Krey \& Babenerd 1976, Karabashev \& Solov'yev 1978, Hay et al. 1992), ship-observed, surface-chlorophyll concentrations (Babenerd \& Krey 1974, Banse 1987b), and mixed-layer depth and phytoplankton-biomass climatologies (Figs. 1 \& 2) strongly suggest that in May almost the entire Arabian Sea attains the 'Typical Tropical Structure' (TTS), first described in the eastern tropical Atlantic (Herbland \& Voituriez 1977, 1979). Shoaling of the mixed layer and a basinwide spread of oligotrophy suggest that following the close of summer monsoon the Arabian Sea again approaches the TTS, although during the fall intermonsoon this trend is apparently stunted by the less intense upper ocean heat gain (Hastenrath \& Greischar 1989).

Although both the northeast and southwest monsoons result in mixed-layer deepening and regional phytoplankton blooms in the Arabian Sea, different mechanisms have been proposed. Climatologies of mixed-layer thickness (Hastenrath \& Lamb 1979a) and phytoplankton biomass as observed by satellite for February (Figs. 1 \& 2) reveal a $30 \mathrm{~m}$ increase in mixedlayer thickness during the northeast monsoon and an approximate doubling of phytoplankton biomass over all but the southeastern Arabian Sea. This seasonal evolution is consistent with the results of Banse \& McClain (1986) and Banse (1987b) who used both ship and satellite observations to identify wintertime phytoplankton blooms in the northern Arabian Sea. These winter blooms are probably due to vertical mixing caused by wind stirring or convective overturn; however, their origin remains somewhat ambiguous (Banse \& McClain 1986).

Upwelling off the coasts of Somalia (Smith \& Codispoti 1980, Schott 1983, Smith 1984) and Oman (Bruce 1974, Smith \& Bottero 1977, Swallow 1984, Elliot \& Savidge 1990, Bauer et al. 1991) during the southwest monsoon yields a phytoplankton bloom (Krey \& Babenerd 1976, 
Banse 1987b, Bauer 1991, Brock et al. 1991) that extends over much of the western Arabian Sea in August (Fig. 2). The portion of this regional bloom that extends over $700 \mathrm{~km}$ seaward of the Omani shelf has been attributed to upward Ekman pumping driven by strong, positive wind-stress curl to the northwest of the Findlater Jet (Findlater 1966) axis (Bauer et al. 1991, Brock et al. 1991, Brock \& McClain 1992). Deepening of the summer mixed layer in the central Arabian Sea (Fig, 1) has been attributed to convergence in the Ekman layer caused by negative wind-stress curl south of the Findlater Jet axis (Rao 1986, McCreary \& Kundu 1989, Naidu \& Rao 1990 , Bauer et al. 1991).

\section{Thermocline irradiance}

Submarine light in the Arabian Sea was monitored during the International Indian Ocean Expedition (Babenerd \& Krey 1974) and subsequent cruises (Smith \& Lane 1981, Hitchcock \& Frazel 1989, Mantoura 1991). Qasim (1982) used historical ship measurements to map the depth of $1 \%$ illumination (euphotic zone) in the northern Arabian Sea. His map combines data from throughout the year and depicts a range in euphotic zone depth of 20 to $60 \mathrm{~m}$ with an average of $40 \mathrm{~m}$. Shoaling of the euphotic zone from south to north in the Arabian Sea is implied, as Qasim (1977) suggested an average thickness of $60 \mathrm{~m}$ for the euphotic zone in the southern Arabian Sea.

Krey \& Babenerd (1976) presented maps of euphotic layer thickness in the Indian Ocean for two 6 mo periods, May through October and November through April. Such maps are not well suited for validating our light modeling, because these half-year periods combine highly contrasting seasons. The Krey \& Babenerd (1976) compilation is based on data collected during the International Indian Ocean Expedition, and depicts an annual range in euphotic layer depth of about 50 to $90 \mathrm{~m}$ for the Arabian Sea.

The coupled light models of Bird (1984) and Sathyendranath \& Platt $(1988,1989)$ predict that, at the close of both the fall and spring intermonsoons, the base of the euphotic zone is below the mixed layer everywhere in the open Arabian Sea (Fig. 3). In November, at the end of the fall intermonsoon, a high in thermocline irradiance exceeding $19 \%$ of the surface irradiance is predicted for a region of shoaled mixed layer centered at $5^{\circ} \mathrm{N}, 55^{\circ} \mathrm{E}$. The spring intermonsoon yields maximum light at the mixed-layer base off Arabia near $17^{\circ} \mathrm{N}, 63^{\circ} \mathrm{E}$. This region coincides with a shoaled mixed layer with phytoplankton pigment concentrations less than $0.10 \mathrm{mg} \mathrm{m}^{-3}$, where light at the mixed-layer depth is estimated to exceed $15 \%$ of that at the surface.
The model predicts that both the northeast and southwest monsoons result in extensive regions in the northern Arabian Sea where less than 1\% of the surface light reaches the uppermost thermocline (Fig. 3). At the close of the northeast monsoon in Febuary, the base of the euphotic zone is predicted to rise into the deepened mixed layer north of about $15^{\circ} \mathrm{N}$. In August this region is more extensive than in winter, and its origin is more complex. As the southwest monsoon hydrography becomes fully developed, the uppermost thermocline is predicted to receive less than $1 \%$ of surface light beneath all areas subject to either upward or downward Ekman pumping or coastal upwelling. Thus, a light-starved thermocline is expected off the Omani and Somali coasts, across the open-sea upwelling northwest of the atmospheric Findlater Jet, and beneath the deepened central Arabian Sea mixedlayer. Note that high-pigment water of the open-ocean upwelling bloom in the northwestern Arabian Sea extends southeastward over the central Arabian Sea mixed layer to intensify light attenuation above the descended thermocline.

Our light modeling predicted the intermonsoons to be seasons of peak light availability for photosynthesis in the upper thermocline of the Arabian Sea, consistent with the observations of subsurface chlorophyll maxima in the spring and fall intermonsoons reported by Krey \& Babenerd (1976) and Hay et al. (1992). The northern Arabian Sea thermocline is predicted to undergo intense and geographically extensive decrease in thermocline irradiance during the southwest monsoon. Consequently, the deepest light propagation is predicted to occur during the seasons of low wind strength between the monsoons (Hastenrath \& Lamb 1979a). This seasonality in light at the base of the mixed layer implies variation in the relative contribution of the thermocline to total, water-column primary production.

\section{Primary production in the western Arabian Sea}

The annual cycle of mixed-layer primary production estimated by the model of Platt \& Sathyendranath (1988) at the RV 'Sonne' station site in the western Arabian Sea includes a massive peak for the southwest monsoon (nearly $2000 \mathrm{mg} \mathrm{C} \mathrm{m} \mathrm{C}^{-1}$ ) and a secondary maximum (about $250 \mathrm{mg} \mathrm{C} \mathrm{m} \mathrm{Cd}^{-1}$ ) for the northeast monsoon (Fig. 5a). As might be inferred from satellite ocean-color, mixed-layer primary production diminishes during the intermonsoons, dropping to less than $50 \mathrm{mg} \mathrm{C} \mathrm{m}^{-2} \mathrm{~d}{ }^{1}$ in April, May and June.

Peaks in thermocline primary production are predicted for the intermonsoons even if thermocline phytoplankton biomass is assumed uniformly oligo- 


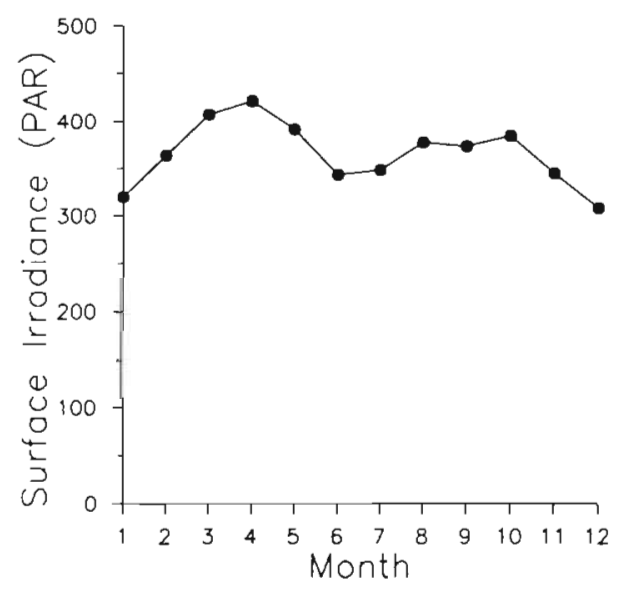

Fig. 6. Annual cycle of model surface irradiance $\left(\mathrm{W} \mathrm{m}^{-2}\right)$ in the wavelength region of photosynthetically available radiation $(400$ to $700 \mathrm{~nm})$ at local noon at the site of the RV 'Sonne' station in the western Arabian Sea. Note that the annual maximum in model surface irradiance occurs during the spring intermonsoon

trophic throughout the year (Fig. 5b). This arises from changes in thermocline irradiance (Fig. 3) mainly due to variation in mixed-layer light attenuation. More fundamentally, increases in thermocline irradiance in the western Arabian Sea during the intermonsoons are a consequence of evolution towards the TTS upon diminution of the winds and mixed-layer heating at the close of each monsoon. Thus, as the surface irradiance increases (Fig. 6), and the mixed-layer shoals and phytoplankton biomass in it decreases (Fig. 7), the hydrography approaches that of unperturbed tropical waters, the natural state of the Arabian Sea in the absence of monsoons. A deep chlorophyll peak that reaches 8.8 times the baseline biomass, such as that observed by the RV 'Sonne' at the close of the spring

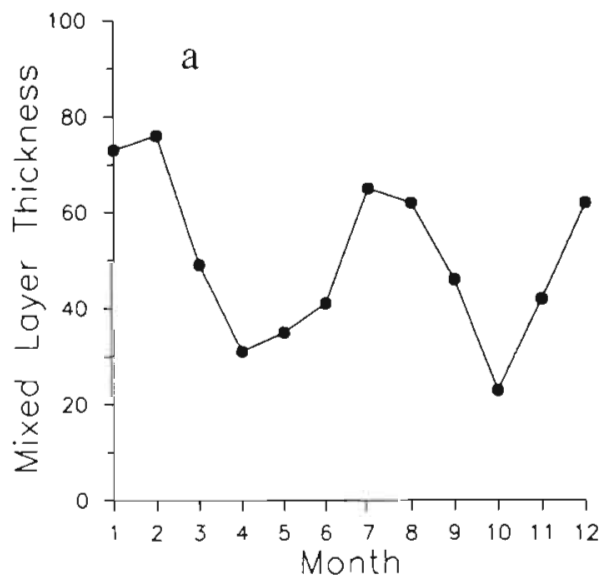

intermonsoon, is a component of the classic TTS (Herbland \& Voituriez 1977, 1979), and it results in a severalfold increase in thermocline primary production during the spring and fall intermonsoons (Fig. 5b). Assuming an SCM of this intensity, the primary production from the thermocline alone in May is estimated to approach $500 \mathrm{mg} \mathrm{C} \mathrm{m} \mathrm{C}^{-2} \mathrm{~d}^{-1}$. Historical vertical profiles strongly suggest that in the northern Arabian Sea the SCM dissipates beneath thickened, eutrophic mixed-layers of the monsoons (Babenerd \& Krey 1974). Further, the low monsoonal thermocline irradiance predicted by the submarine light model severely limits thermocline primary production, regardless of the concentration of viable phytoplankton biomass below the mixed layer.

Even in the absence of an SCM, most of the total water-column primary production (Fig. 5c) and light attenuation by chlorophyll (Fig. 8 ) is predicted to occur in the thermocline during April, May and June (Fig. 5c). The inclusion of an SCM greatly enhances the model prediction of light attenuation by chlorophyll and carbon assimilation in the thermocline during the spring intermonsoon, and results in a fall intermonsoon period of deep primary production exceeding that estimated for the mixed layer. Vertical chlorophyll profiles observed in the western Arabian Sea during the spring intermonsoon typically reveal SCMs with chlorophyll concentrations greater than 10 times an oligotrophic value (Babenerd \& Krey 1974). Thus, the model predicts that during the spring intermonsoon. depth-integrated primary production in the thermocline should be about 10-fold greater than depthintegrated mixed-layer primary production (Fig. 5c). The portion of total water column production that occurs in the intermonsoon thermocline may be even higher than that predicted by this model, because in the nutrient-rich thermocline, the initial slope $\alpha^{B}[\mathrm{mg} \mathrm{C}$

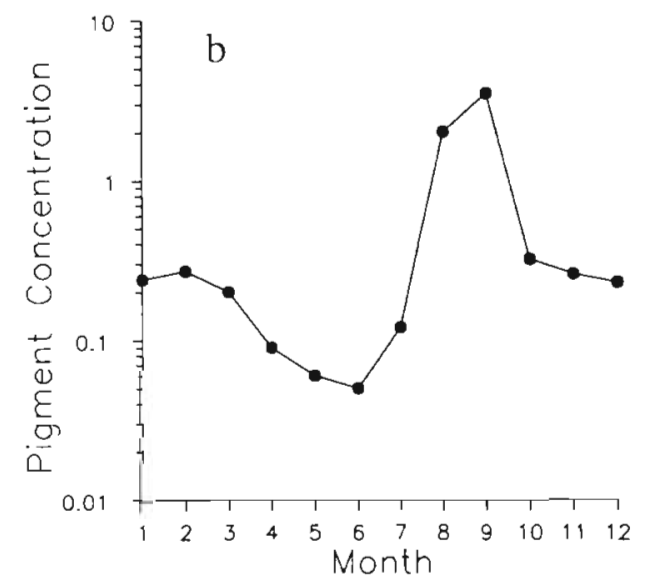

Fig. 7. Monthly mixed-layer depth (m), and monthly mixed-layer chlorophyll ( $\mathrm{mg} \mathrm{m}^{-3}$ ), through the year at the RV 'Sonne' station of May 24, 1986, in the western Arabian Sea. Values plotted are from the Hastenrath \& Greischar (1989) and CZCS-based climatologies used in light and primary production modeling 


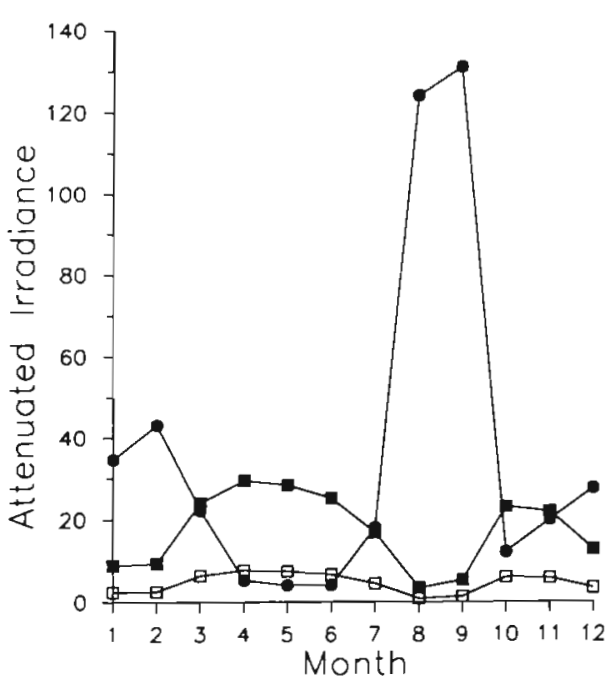

Fig. 8. Model estimate of the annual cycle of total irradiance $\left(\mathrm{W} \mathrm{m}^{-2}\right)$ attenuated by: chlorophyll in the mixed layer $(\bullet)$ chlorophyll in a thermocline with a SCM in which the chlorophyll concentration reaches 10 times the oligotrophic baseline value ( $\boldsymbol{0}$ ), and attenuated by chlorophyll in an oligotrophic thermocline ( $[$ ) with vertially uniform chlorophyll concentration $\left(0.06 \mathrm{mg} \mathrm{m}^{-3}\right)$ at the site of the RV 'Sonne' station in the western Arabian Sea

$\left.(\mathrm{mg} \mathrm{chl} \mathrm{a})^{-1} \mathrm{~h}^{-1}\left(\mathrm{~W} \mathrm{~m}^{-2}\right)^{-1}\right]$ of this curve is likely to be higher than it is in the oligotrophic mixed layer (Platt et al. 1992). In the light-limited thermocline regime, the consequence would parallel that for an intensified SCM, enhanced partitioning of primary production into the thermocline relative to the mixed layer.

Although an explanation for the SCM observed during the spring intermonsoon in the western Arabian Sea is outside the scope of this paper, the results of our model experiment favor the hypothesis of enhanced growth in a pycnocline with abundant light and nitrate (Jamart et al. 1977). An SCM in a stable oceanographic regime normally consists of shade-adapted plants, exists between the 1 and $0.1 \%$ light levels, and traps nutrients difusing up from a nutricline immediately below (Banse 1987a, Dortch 1987, Longhurst \& Harrison 1989). The model surface irradiance increases during the spring intermonsoon at the location of the RV 'Sonne' station (Fig. 6), and in May, the uppermost pycnocline at this site in the western Arabian Sea is expected to receive $14 \%$ of the surface light, or about $37 \mathrm{~W} \mathrm{~m}^{-2}$. Therefore, a chlorophyll peak just below the western Arabian Sea mixed layer in May should experience comparatively high irradiance. Given that a sharp nitricline corresponds to the upper pycnocline (Ryther \& Menzel 1965, Brock et al. 1992), a nitraterich layer should be present in the lower euphotic zone during the spring intermonsoon, as surface irradiance rises towards the summer solstice under cloud-free skies, and light attenuation drops in the increasingly thin and oligotrophic mixed layer. We believe that the extreme seasonality of the deep light field and sharp nutrient stratification of the western Arabian Sea allows an SCM to form during the spring intermonsoon. In our view, the nitricline is light-flooded between the monsoons, driving photosynthesis below the mixed-layer, in an environment that is, at least initially, nutrient-rich. Further, phytoplankton cells beneath the intermonsoon mixed layer should experience a gradual increase in light through the season that would further enhance photosynthesis (Fig. 8).

The sediment trap deployment in the Arabian Sea (Nair et al. 1989) provides evidence for export production from the SCM in the western Arabian Sea during the intermonsoons. The total particlate fluxes captured by the western $\operatorname{trap}\left(16.18^{\circ} \mathrm{N}, 60.15^{\circ} \mathrm{E}\right)$ increase at the close of each intermonsoon prior to the onset of vigorous monsoon winds. Fluxes reported for the early intermonsoon months of March, April and October are consistently below $20 \mathrm{mg} \mathrm{m} \mathrm{m}^{-2} \mathrm{~d}^{-1}$, yet rise in May to exceed $40 \mathrm{mg} \mathrm{m}^{-2} \mathrm{~d}^{-1}$ and in November-December to above $100 \mathrm{mg} \mathrm{m}^{-2} \mathrm{~d}^{-1}$. Downward transit of organic carbon from an SCM in May and November-December should be enhanced by its position within or below the primary density interface and directly above an intense oxygen minimum zone from 200 to $1500 \mathrm{~m}$ (Wyrtki 1971). The rain of particulate organic carbon from the SCM should upon minimal sinking enter this oxygen minimum zone, where heterotrophic respiration and decomposition is severely inhibited (Vinogradov \& Voronina 1961, Vinogradov 1970). The observations at the western Arabian Sea sediment trap (Nair et al. 1989) showed that organic carbon constituted the highest percentage of the total flux $(7.1 \%)$ during the spring intermonsoon, consistent with our expectation of increased deep primary production in this season (Nair et al. 1989).

The widespread SCM in the Arabian Sea just prior to the onset of summer monsoon upwelling could be the precursor of the extensive phytoplankton bloom observed across the western Arabian Sea in summer (Krey \& Babenerd 1976, Banse 1987b, Bauer et al. 1991, Brock et al. 1991, Brock \& McClain 1992). Given an open-sea upwelling rate of $1.5 \mathrm{~m} \mathrm{~d}^{-1}(\mathrm{M}$. Luther pers. comm.) and a $30 \mathrm{~m}$ thick mixed-layer, this preexisting subsurface bloom could reach the surface in $20 \mathrm{~d}$ to create a regional phytoplankton bloom. Uplift of an SCM requires no horizontal advection or nutrient fluxes into the mixed layer to yield a summer, surfacelayer bloom, visible to satellite ocean-color sensors, over all of the Arabian Sea north of the Findlater Jet axis. The nitricline is also upwelled, and the mixed layer persists in spite of Ekman layer divergence, implying entrainment of nutrient-charged water into a 
continually reforming mixed layer. Thus, the regional, southwest monsoon bloom of phytoplankton is envisioned to begin in the upper thermocline in a nutrientrich, light-limited environment during the spring intermonsoon when the Arabian evolves towards the state of unperturbed tropical waters.

\section{CONCLUSIONS}

Our examination of climatological ship-data and satellite-based ocean-color observations has verified that the mixed layer across most of the Arabian Sea shoals and becomes oligotrophic during the intermonsoon seasons in fall and spring. In May, at the close of the season of greatest heating, the open Arabian Sea approaches the state of an unperturbed tropical ocean with mixed-layer depths shallower than $50 \mathrm{~m}$ and satellite-observed pigment concentrations less than $0.1 \mathrm{mg} \mathrm{m}^{-3}$. The northeast monsoon results in phytoplankton blooms in the northern Arabian Sea, and a deepening of the mixed layer over most of the basin. Monsoonal upwelling driven by the southwest monsoon yields a massive phytoplankton bloom that extends over much of the western Arabian Sea in late summer. Negative wind-stress curl to the south of the Findlater Jet forces convergence in the Ekman layer and deepening of the mixed layer in summer in the central Arabian Sea.

Our light model computations predict that seasonal changes in the mixed layer create variations in the thermocline light field through the annual cycle. According to the model results, the base of the euphotic zone is below the mixed layer over all of the open Arabian Sea at the close of the fall and spring intermonsoons. Both the summer and winter monsoons result in a euphotic zone contained wholly within the mixed layer of the northern Arabian Sea. In August, at the final phases of the development of the southwest monsoon hydrography, the thermocline is predicted to receive less than $1 \%$ of surface light in areas subject to either mixed-layer eutrophication or deepening, which is most of the Arabian Sea north of $10^{\circ} \mathrm{N}$.

The photosynthesis-irradiance model of Platt \& Sathyendranath (1988) predicts strong seasonality in the partitioning of primary production between the mixed layer and the thermocline at $14.36^{\circ} \mathrm{N}, 57.38^{\circ} \mathrm{E}$ in the western Arabian Sea. The computed mixedlayer primary production reaches an intense peak during the southwest monsoon and a secondary peak during the northeast monsoon. These 2 peaks are separated by intermonsoons of extremely low mixedlayer production. In contrast, modeled primary production in the thermocline peaks during the intermonsoons, even with phytoplankton biomass below the mixed layer held vertically uniform and oligotrophic throughout the year. If we assume a deep chlorophyll peak similar to that observed at this location by the RV 'Sonne' in 1986, the estimated primary production from the thermocline in May would approach $500 \mathrm{mg} \mathrm{C} \mathrm{m}{ }^{-2} \mathrm{~d}^{-1}$, which is an order of magnitude greater than the production from the mixed layer for this month and location. Thermocline production is predicted to exceed that in the mixed layer in April, May and June even in the most conservative case of a consistently oligotrophic upper thermocline. Inclusion of a deep chlorophyll maximum greatly enhances modeled deep production during the spring and fall intermonsoons

We believe that the nitricline of the western Arabian Sea is flooded with light between the monsoons, driving photosynthesis below the mixed layer, which is not nutrient limited. A deep phytoplankton bloom forced by this mechanism could be brought to the surface rapidly at the onset of the southwest monsoon by Ekman pumping across the Arabian Sea north of the Findlater Jet. Thus, our model experiment suggests that the extensive phytoplankton bloom during the southwest monsoon in the western Arabian Sea begins in the upper thermocline in a nutrient-rich, lightlimited environment during the preceeding spring intermonsoon, the season of greatest mixed-layer oligotrophy.

Acknowledgements. The work presented in this paper was supported, in part, by the Office of Naval Research, the National Aeronautics and Space Administration, the European Space Agency, and the Department of Fisheries and Oceans, Canada. Additional support was provided by the Natural Sciences and Engineering Research Council through Operating Grants to S.S. and T.P., and a Visiting Fellowship to J.B. The authors thank the Nimbus Project at NASA/GSFC and the University of Miami for Coastal Zone Color Scanner data products, and B. Hay and M. Petzold for pigment concentration analyses of water samples collected during Cruise SO-42 of the RV 'Sonne' J.B. thanks Alan Longhurst for encouragement and stimulating discussion. This work was carried out as part of the Canadian contribution to the Global Ocean Flux Study.

\section{LITERATURE CITED}

Babenerd, B., Krey, J. (1974). Indian Ocean: collected data on primary production, phytoplankton pigments, and some related factors. Institut für Meereskunde an der Universität Kiel, Kiel

Banse, K. (1987a). Clouds, deep chlorophyll maxima and nutrient supply to the mixed-layer of stratified water bodies. J. Plankton Res. 9(5): 1031-1036

Banse, K. (1987b). Seasonality of phytoplankton chlorophyll in the central and northern Arabian Sea. Deep Sea Res. 34: $713-723$

Banse, K. McClain, C. R. (1986). Satellite-observed winter blooms of phytoplankton in the Arabian Sea. Mar. Ecol. Prog. Ser. 34: 201-211 
Bauer, S., Hitchcock, G. L., OIson, D. B. (1991). Influence of monsoonally-forced Ekman dynamics upon surface-layer depth and plankton biomass distribution in the Arabian Sea. Deep Sea Res. 38(5): 531-553

Bird, R. E. (1984). A simple, solar spectral model for directnormal and diffuse horizontal irradiance. Sol. Energy 32 461-471

Brock, J C., McClain, C. R. (1992). Interannual variability of the southwest monsoon phytoplankton bloom in the northwestern Arabian Sea. J. geophys. Res. 97(C1): 733-750

Brock J C., McClain, C. R., Hay, W. W. (1992). A southwest monsoon hydrographic climatology for the northwestern Arabian Sea. J. geophys. Res. 97(C6): 9455-9465

Brock, J. C., McClain, C. R., Luther, M. E., Hay, W. W. (1991). The phytoplankton bloom in the northwestern Arabian Sea during the southwest monsoon of 1979 . J. geophys Res. 96(C11): 20623-20642

Bruce, J. G. (1974). Some details of upwelling off the Somali and Arabian coasts. J. mar. Res. 32: 419-423

Colburn, J. G. (1975). The thermal structure of the Indian Ocean. University of Hawaii Press, Honolulu

Currie, R. I., Fisher, A. E., Hargreaves, P. M. (1973). Arabian Sea upwelling. In: Zeitzschel, B. (ed) The biology of the Indian Ocean. Springer-Verlag, New York, p. 37-52

Dortsch, Q. (1987). The biochemical composition of plankton in a subsurface chlorophyll maximum. Deep Sea Res. 34(5-6): 705-712

Eliiot, A. J., Savidge, G. (1990). Some features of upwelling off Oman. J. mar. Res. 48: 319-333

Feldman, G., Kuring, N., Ng, C., Esaias, W., McClain, C., Elrod, J., Maynard, N., Endres, D., Evans, R., Brown, J., Walsh, S., Carle, M., Podesta, G. (1989). Ocean-color: availability of the global data set. EOS (Trans. Am. Geophys. Un.) 70(23): 634

Findlater, J. (1966). Cross-equatorial jet streams at low level over Kenya. Meteorol. Mag. 95: 353-364

Gieskes, W. W. G., Kraay, G. W., Tussen, S. B. (1978). Chlorophylls and their degradation products in the deep pigment maximum layer of the tropical North Atlantic. Neth. J. Sea Res. 12: 195-204

Gordon, H. R., McCluney, W. R. (1975). Estimation of the depth of sunlight penetration in the Sea for remote sensing. Appl. Optics 14(2): 413-416

Gordon, H. R., Morel, A. Y (1983). Remote assessment of ocean-color for interpretation of satellite visible imagery. Springer-Verlag. New York

Hastenrath, S., Greischar, L. L. (1989). Climatic atlas of the Indian Ocean. Part III: Upper-ocean structure. University of Wisconsin Press, Madison.

Hastenrath, S., Lamb, P. (1979a). Climatic atlas of the Indian Ocean. Part I: Surface circulation and climate. University of Wisconsin Press, Madison

Hastenrath, S., Lamb, P. (1979b). Climatic atlas of the Indian Ocean. Part II: The oceanic heat budget. University of Wisconsin Press, Madison

Hay, B. J., McClain, C. R., Petzold, M. (1992). An assessment of the NIMBUS-7/CZCS calibration for May 1986 using satellite and in situ data from the Arabian Sea. Remote Sens. Environ. 43: 35-46

Hayward, T L., Venrick, E. L., McGowan. J. A. (1983). Environmental heterogeneity and plankton community structure in the central North Pacific. J. mar. Res. 41. 711-729

Herbland, A., Voituriez, B. (1977). Production primaire, nitrate et nitrite dans l'Atlantique tropical, 1 - Distribution du nitrate et production primaire. Cah. ORSTOM, Oceanogr. 15: 47-56

Herbland, A., Voituriez, B. (1979). Hydrological structure analysis for estimating the primary production in the tropical Atlantic Ocean. J. mar. Res. 37:87-101

Hitchcock, G. L., Frazel, D. W. (1989). Primary productivity and pigment biomass in the Arabian Sea: R.R.S. Charles Darwin Cruise CD25. Nova University Oceanographic Center Technical Report NOVA-89-1, Dania, FL

Jamart, B. M., Winter, D. F., Banse, K., Anderson, G. C., Lam, R. K. (1977). A theoretical study of phytoplankton growth and nutrient distribution in the Pacific Ocean off the northwestern U.S. coast. Deep Sea Res. 24: 753-772

Kabanova, Y. G. (1968). Primary production of the northern part of the Indian Ocean. Oceanology 8(2): 214

Karabashev, G. S., Solov'yev, A. N. (1978). Relation between the fluorescence maxima of phytoplankton pigments and the location of the seasonal pycnocline. Oceanology $18(4)$ : $468-471$

Krey, J., Babenerd, B. (1976). Phytoplankton production atlas of the international Indian Ocean expedition. Institut für Meereskunde an der Universität Kiel, Kiel

Longhurst, A. R., Harrison, W. G. (1989). Vertical nitrogen flux from the oceanic photic zone by diel migrant zooplankton and nekton. Deep Sea Res. 35: 881-890

Mann, K. H., Lazier, J. R. N. (1991). Dynamics of marine ecosystems, biological-physical interactions in the oceans. Blackwell Scientific Publications, Cambridge

Mantoura, R. F. C. (1991). Nutrient and trace metal biogeochemical cycling in the NW Indian Ocean. Cruise ReportRRS Charles Darwin Cruise CD 16/86. Plymouth Marine Laboratory, Plymouth

McCreary, J. P., Kundu, P. K. (1989). A numerical investigation of sea surface temperature variability in the Arabian Sea. J. geophys. Res. 94(C11): 16097-16114

Molinari, R. L., Swallow, J., Festa, J. F. (1986). Evolution of the near-surface thermal structure in the western Indian Ocean during FGGE, 1979. J. mar. Res. 44:739-763

Morel, A., Prieur, L. (1977). Analysis of variations in ocean colour. Limnol. Oceanogr. 22: 709-722

Naidu, V. S., Rao, G. R. L. (1990). Ekman pumping velocity and depth of surface mixed-layer of the north Indian Ocean during southwest monsoon. Indian J. mar. Sci. 19: $257-260$

Nair, R. R., Ittekkot, V., Manganini, S. J., Ramaswamy, V., Haake, B., Degens, E. T., Desai, B. N. (1989). Increased particle flux to the deep ocean related to monsoons. Nature 338: 749-751

Paltridge, G. W., Platt, C. M. R. (1976). Radiative processes in meteorology and climatology. Elsevier, New York

Platt T., Caverhill, C., Sathyendranath, S. (1991). Basin-scale estimates of oceanic primary production by remote sensing: the North Atlantic. J. geophys. Res. 96(C8) $15147-15159$

Platt, T., Sathyendranath, S. (1988). Oceanic primary production: estimation by remote sensing at local and regional scales. Science 241: 1613-1620

Platt, T., Sathyendranath, S., Ulloa, O., Harrison, W. G. Hoepffner, N., Goes, J. (1992). Nutrient control of phytoplankton photosynthesis in the western North Atlantic. Nature 356: 229-231

Qasim, S. Z. (1977). Biological productivity of the Indian Ocean. Indian J. mar. Sci. 6: 122-137

Qasim, S. Z. (1982). Oceanography of the northern Arabian Sea. Deep Sea Res. 29(9A): 1041-1068

Rao, R. R. (1986). Cooling and deepening of the mixed-layer in the central Arabian Sea during MONSOON-77: observations and simulations. Deep Sea Res. 33(10): 1413-1424

Rao, R. R., Molinari, R. L., Festa, J. F. (1989). Evolution of the climatological near-surface thermal structure of the tropi- 
cal Indian Ocean. 1. Description of monthly mean mixedlayer depth, and sea surface temperature, surface current, and surface meteorological fields. J. geophys. Res. 94(C8): $10801-10815$

Ryther, J. H., Hall, J. R., Pease, A. K., Bakun, A., Jones, M. M. (1966). Primary organic production in relation to the chemistry and hydrography of the western Indian Ocean. Limnol. Oceanogr. 11: 371-380

Ryther, J. H., Menzel, D. W. (1965). On the production, composition, and distribution of organic matter in the western Arabian Sea. Deep Sea Res. 12: 199-209

Saijo, J. (1973). The formation of the chlorophyll maximum in the Indian Ocean. In: Zeitzschel, B. (ed.) The biology of the Indian Ocean. Springer-Verlag, New York, p. 171-173

Sathyendranath, S., Platt, T. (1988). The spectral irradiance field at the surface and in the interior of the ocean: a model for applications in oceanography and remote sensing. J. geophys. Res. 93(C8): 9270-9280

Sathyendranath, S., Platt, T. (1989). Computation of aquatic primary production: extended formalism to include effect of angular and spectral distribution of light. Limnol. Oceanogr. $34: 188-198$

Schott, F. (1983). Monsoon response of the Somali Current and associated upwelling. Prog. Oceanogr. 12: 357-381

Schott, F., Swallow, J. C., Fieux, M. (1990). The Somali Current at the equator: annual cycle of currents and transports in the upper $1,000 \mathrm{~m}$ and connection to neighboring latitudes. Deep Sea Res. 37 1825-1848

Smith, E. L. (1936). Photosynthesis in relation to light and carbon dioxide. Proc. natl Acad. Sci U.S.A. 504-511

Smith, R. L., Bottero, J. S. (1977). On upwelling in the Arabian Sea. In: Angel, M. (ed.) A voyage of Discovery. Pergammon Press, New York, p. 291-304

This article was submitted to the editor
Smith, S. L. (1984). Biological indications of active upwelling in the northwestern Indian Ocean in 1964 and 1979, a comparison with Peru and northwest Africa. Deep Sea Res. 31. 951-967

Smith, S. L., Codispoti, L. A. (1980). Southwest monsoon of 1979: chemical and biological response of Somali coastal waters. Science 209: 597-600

Smith, S. L., Lane, P. V. Z. (1981). Biological oceanography of the Somali Current data report. Oceanographic Sciences Div., Brookhaven National Laboratory, Upton, NY

Swallow, J. C. (1984). Some aspects of the physical oceanography of the Indian Ocean. Deep Sea Res. 31: 639-650

Venrick, E. L., McGowan, J. A., Mantyla, A. W. (1973). Deep chlorophyll maximum of photosynthetic chlorophyll in the Pacific Ocean. Fish. Bull. U.S. 71: 41-52

Vinogradov, M. E. (1970). Vertical distribution of the oceanic zooplankton. Israel Progress in Science Publication 5513, Ketter Press, Jerusalem

Vinogradov, M. E., Voronina, N. M. (1961). Influence of oxygen deficit on the distribution of plankton in the Arabian Sea. Okeanologia 1: 670-678

Webster, P. J. (1987). The elementary monsoon. In: Fein, J. S., Stephens, P. L. (eds.) Monsoons. John Wiley, New York, p. $3-32$

Wright, P. B. (1988). An atlas based on the 'COADS' data set: fields of mean wind, cloudiness and humidity at the surface of the Global Ocean, Report No. 14. Max-PlanckInstitut fur Meteorologie, Hamburg

Wyrtki, K. (1971). Oceanographic atlas of the international Indian Ocean expedition. National Science Foundation, Washington, DC

Yentsch, C. S. (1965). Distribution of chlorophyll and phaeophytin in the open ocean. Deep Sea Res. 12: 653-666

Manuscript first received: October 28, 1992

Revised version accepted: June 29, 1993 